\title{
THE CHINESE DREAMS OF
ARABIAN TRADERS IN YIWU Wen Meizhen
}

$\mathrm{I}$ NTERVIEWED BY JINHUA DAILY in March 2016, Said Bahaji, a trader from Jordan, spoke with enthusiasm of Yiwu 义乌, a county-level city in eastern Zhejiang province: 'Yiwu is an amazing place, a land of opportunity where we can achieve our Chinese dream'. Said Bahaji is one of about 4,000 traders from North Africa and the Middle East who have settled down in Yiwu, in pursuit of their own 'Chinese dreams'. Playing the role of intermediaries, these 'Arab Traders' help buyers from all over the world, but especially from their region, search for and buy products in Yiwu and elsewhere in China. ${ }^{3}$ Their businesses and personal stories have recently become the focus of Chinese media attention as a result of the launch of the Belt and Road Initiative, which emphasises 'people-to-people' bonds (in addition to the more common focus on infrastructure). However, the connection of these Arab traders with Yiwu predates the launch of this policy.

Yiwu is an inland city located in the centre of Zhejiang province. It was named the 'Largest Commodity Wholesale Market in the World' by the United Nations, the World Bank, and Morgan Stanley in 2005. Yiwu is also popularly known as the 'world's supermarket' - a national and international centre for the collection and distribution of small commodities. It plays the role of collecting millions of small products produced in different places in China, and then distributing them all over the world. A local official once estimated that if you went to visit every store for just five minutes, it would take 


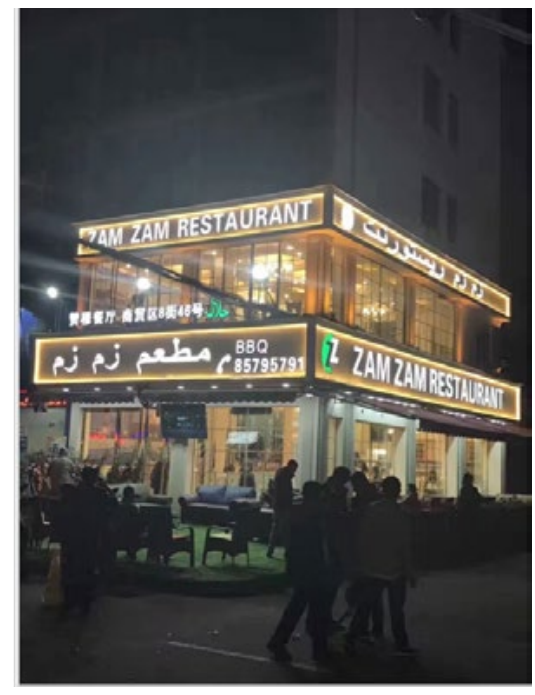

An Arabian restaurant in the commercial district in Yiwu

Photo: Wen Meizhen

over two years to visit all the shops in Yiwu. They sell every conceivable type of small commodity, from hardware to clothes, at very low prices, and there are many customers for such inexpensive goods in North Africa and the Middle East.

Most of the North African and Middle Eastern traders who end up in Yiwu have followed one of four different paths. The majority moved from Indonesia, Thailand, or Singapore when the 1998 financial crisis in Asia greatly increased the price of South-East Asian products. Others, from countries in- cluding Yemen, Palestine, and Egypt, originally came to China to study on Chinese government scholarships and then stayed on after graduation, encouraged by business opportunities in Yiwu. These former students, now fluent in Chinese and with large social networks after years in the country, were very well placed to establish businesses. A third path involved former Arabic-Chinese interpreters from the Xinjiang Uyghur Autonomous Administration Area, who had previously done interpreting in that region, and later brought the Arab traders to Yiwu to import goods directly from factories in south-east China. Finally, some traders came to Yiwu after attending trade exhibitions organised by both Chinese government and non-government organisations in a range of North African and Middle Eastern countries. More than 100 companies have been responsible for organising expos in different provinces in China and overseas to advertise products in Yiwu.

The presence of these traders has significantly contributed to the development of international trade from Yiwu. Forty-seven per cent of the city's total exports in 2015 were shipped to North African and Middle Eastern markets, and these markets 
are expected to expand greatly in the future. An important factor behind this increasing trade was the completion in March 2016 of a 6,500-mile railway connecting Yiwu with Tehran via Kazakhstan, Kyrghyzstan, Uzbekistan, and Turkmenistan. This has greatly reduced transport costs compared with existing shipping routes, transforming Tehran into a hub connecting China with the West. Many products from Yiwu are now delivered by train to Tehran first, before being delivered to other countries in the Middle East and North Africa, at much lower cost than in the past.

These Arab traders have also influenced Yiwu society and culture. The large number of Middle Eastern restaurants and coffee shops on Chouzhou Road 稠州路 gives the area an exotic feeling, especially in the evening, when the traders gather at the outdoor tables of coffee shops, smoking hookahs (pipes). In addition, four private schools have opened in the city - one belonging to a Yemeni trader, one owned by an Iraqi, and two organised by Egyptians. These four schools mainly teach students in Arabic, with one of the Egyptian schools opting for both English and Arabic. All four schools follow the same timetable as in their ori- gin counties. With the increasing number of single, young male Arab traders' presence in Yiwu, there has also been an increase in intermarriages between Chinese women and Middle Eastern or North African men. According to the data provided by a local Imam, between 2000 and 2016, more than 500 intermarriages between Chinese women and Arab men were registered in the local mosque.

While Yiwu provides a means of realising the traders' 'Chinese dream', it is also a life full of uncertainty. The steady increase in the price of Chinese goods resulting from rising labour, material, and rental costs has made these goods less competitive in their home markets and the traders have started to source cheaper products from other countries. Even though many are still living in Yiwu, there is a tendency for Arab traders to move to other countries once they find stable and cheaper supply chains.

This is compounded by the fact that China does not encourage permanent immigration. The state has sought to strengthen its political and commercial relationships with the Middle East and North Africa, encouraging Chinese entrepreneurs to invest in the Middle East and North Africa. 
Yet China changes its visa application process frequently and is also tightening the controls on foreigners working in China, which has discouraged more from coming, and inhibited those already there from making long-term plans. Access to education for the traders' children has also been a source of frustration, as they are not allowed to enroll in local public schools, and there are not enough places at the private schools to meet demand. In addition, as Muslims, some traders also fear that their children are not being given a sufficient religious education when their children stay and study in China. As Egyptian trader Samire Zawai told me in his office in 2016: 'I have been in China more than eighteen years, I have already considered Yiwu as my second home town, but I do not know whether I will continue to stay in Yiwu when the price of products increased year by year, and the government has stricter visa policy towards the foreigners'. Until such matters are resolved, the dreams of Arab traders in Yiwu may have to remain just that. 
This text is taken from China Story Yearbook 2017: Prosperity, edited by Jane Golley and Linda Jaivin, published 2018 by ANU Press, The Australian National University, Canberra, Australia.

doi.org/10.22459/CSY.04.2018.04B 